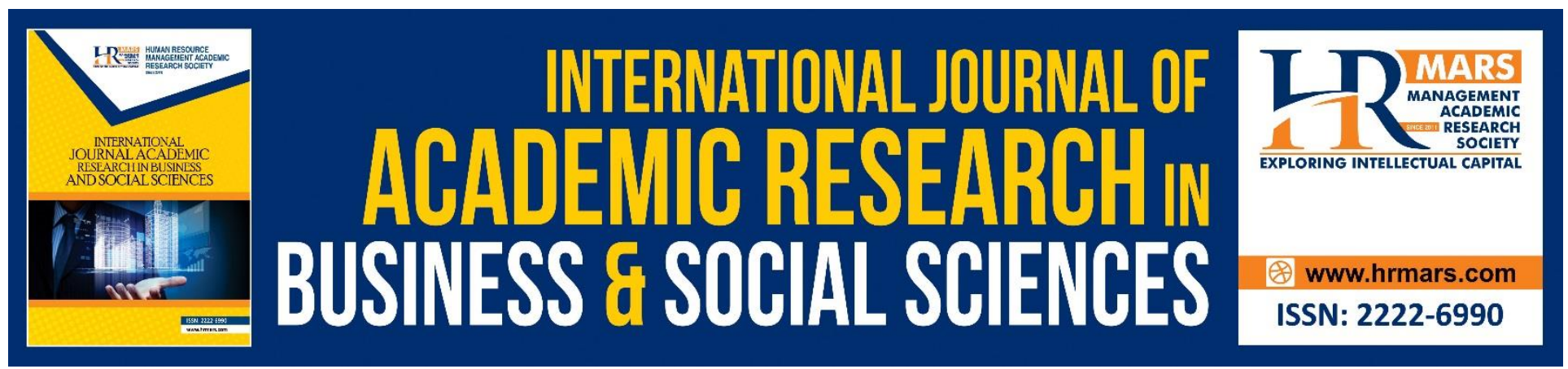

\title{
The Influence of Animism on the Customs and Culture of the Iban Community
}

Jacqlyn Patricia Jelani and Salmah Jan Noor Muhammad

To Link this Article: http://dx.doi.org/10.6007/IJARBSS/v8-i8/4631 DOI: $10.6007 /$ IJARBSS/v8-i8/4631

Received: 17 June 2018, Revised: 26 July 2018, Accepted: 29 July 2018

Published Online: 23 August 2018

In-Text Citation: (Jelani \& Muhammad, 2018)

To Cite this Article: Jelani, J. P., \& Muhammad, S. J. N. (2018). The Influence of Animism on the Customs and Culture of the Iban Community. International Journal of Academic Research in Business and Social Sciences, $8(8), 763-774$.

Copyright: (C) 2018 The Author(s)

Published by Human Resource Management Academic Research Society (www.hrmars.com)

This article is published under the Creative Commons Attribution (CC BY 4.0) license. Anyone may reproduce, distribute, translate and create derivative works of this article (for both commercial and non-commercial purposes), subject to full attribution to the original publication and authors. The full terms of this license may be seen at: http://creativecommons.org/licences/by/4.0/legalcode

Vol. 8, No. 8, August 2018, Pg. $763-774$

Full Terms \& Conditions of access and use can be found at http://hrmars.com/index.php/pages/detail/publication-ethics 


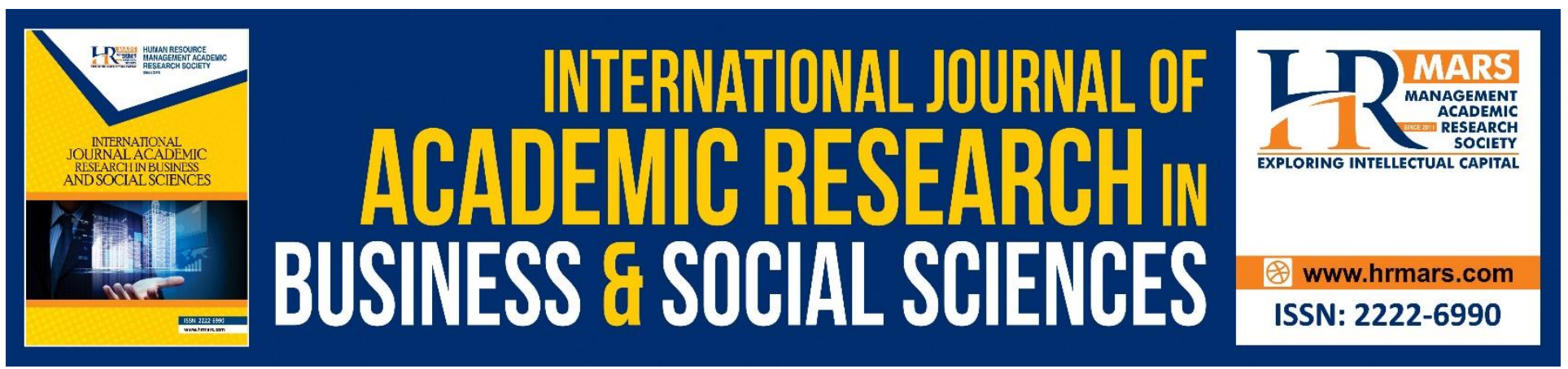

\title{
The Influence of Animism on the Customs and Culture of the Iban Community
}

\author{
Jacqlyn Patricia Jelani and Salmah Jan Noor Muhammad \\ Faculty of Modern Languages and Communication, Universiti Putra Malaysia, 43400 UPM Serdang, \\ Selangor, Malaysia
}

\begin{abstract}
This study is about the Iban race which is one of the largest ethnic groups in Sarawak where they can be found from Sri Aman, all the way up to Miri, Bintulu and Limbang. The Iban people are also known as Sea Dayaks due to their skills in hunting, farming and adherence to traditional customs. The villages of the Iban people are mainly located on river shores and hillsides. Thus, the objective of this study is to identify and discuss the aspects of how animism influenced the customs and cultures of the Iban people in Hikayat Keling Gerasi Nading (1998). This study uses text analysis methods and approaches based on Sociology of Literature, introduced by Alan Swingewood (1972) as a consolidation in this study. The findings showed that there are elements of animism in Hikayat Keling Gerasi Nading (1998) such as consorting with faith healers and witch doctors, beliefs in spirits of the dead and believing in premonition. Therefore, it is hoped that this study would be beneficial to researchers of anthropology to learn about the customs and culture of the Iban community.

Keywords: Beliefs, Animism, Tradition, Culture, Iban community
\end{abstract}

\section{Introduction}

The meaning of literature is the art of covering all aspects and using language that is creative. Abu Bakar Hamid, (1997) stated that literature is an art of thought and a combination of entertainment and beauty of language. In addition, literary works are also found to be educational, where the thoughts of the author as well as the ideas and the production of the literary works displays the views and thoughts of the author where he wishes to share with his readers. In addition, the work itself is created from a combination of taste, attentiveness and sensitivity to things that are seen and experienced by a society where the author resides in and it is expressed in the literary work.

It is therefore, literature and society are mutually linked between one another. All that appears in literary works are the stories of the society. According to Anwar Ridwan (1986) literary works will not be grand and priceless if the world of society living is not learned deeply. Therefore, it is clear that literary works and life could not be separated. Then in this sense, it shows that literature is meaningless if a community's real life is not reflected in the literature. Literature is the medium by which the author employs to the society through true life story which happens in the literary works. 
INTERNATIONAL JOURNAL OF ACADEMIC RESEARCH IN BUSINESS AND SOCIAL SCIENCES

Vol. 8, No. 8, August 2018, E-ISSN: 2222-6990 @ 2018 HRMARS

Next, according to E.B. Taylor (1965), the word animism is derived from the word anima which means the belief in supernatural creatures. Other than that, this belief in the supernatural and spirits is the base of early religious beliefs where it dominated the human thinking in ancient times, since they have not yet recognize the tide of technology and modernity. Furthermore, the meaning of animism is believing that nature has humanlike thoughts and actions, where this applies to plants and animals, inanimate objects, geographical parts such as hills, deserts, forest, caves, ocean and also natural phenomenon such as rain and lightning where all these things has a spirit (or soul) or spiritual elements.

Typically, the Iban people have a unique and special residence namely the longhouse. The construction of longhouses have certain factors where among them is the ability to ward off invasions from enemies and wild beasts. According to Henry (1998) the meaning of "Iban" is believed to have originated from the title "ivan" given by the Kayan society which means 'brave outsiders'. Therefore, the Iban people are most likely to be called as such due to their famous legend as a race of headhunters (Borneo Head Hunters) who beheads their enemies which is an act to prove their courage especially for the men who are about to be wed.

\section{Literature Review}

Studies on the Iban race have already begun long ago in 1900 where an Iban language dictionary was published, namely the Sea Dayak Dictionary by W. Howell and D.J.S Bailey. This was then followed by the year 1976 with the production of books by Benedict Sandin (1976), titled Iban Way of Life and Iban Adat and Augury (1980). Then it was further followed by an Iban scholar named Henry Gana Ngadi (1998) with a book titled Iban Rites of Passage and Some Related Ritual Acts: A Description of Forms and Functions. The evolving world of writing has brought on numerous studies on the Iban community. However, most of the previous studies covered different aspects and their importance.

Among them are studies on the aspects of language and observational study such as those by Harishon Radzi and Phylisia anak David (2012) and studies by Chong Shin, Herpanus Antam, and Remmy Gendat (2014). In addition, there are also studies by Hamdan Abdul Wahab, Imran Ho Abdullah, Mohammed Azlan and Khazriyati Salehuddin (2016). Further reviews of the researches focused more on the use of language in the Iban language.

Moreover, the studies now have shifted to the aspects of tradition and culture. Through observation, research on the aspects of culture is now a popular study among researchers. Among them are studies by Noria Tugang and Anna Durin (2016), Anna Durin, Zarina Mohd. Shah, Bernice Helena and Mohd. Ghazali Abdullah (2011), Saptiana Sulastri (2017), Asmiaty Amat (2011) and Asmiaty Amat and Lokman Abdul Samad (2016). Past research have also touched on the importance of pua kumbu and taboh music as well as the effect of the New Malay Literature on the Iban people which aims at expanding the $D a^{\prime}$ wah of Islamic faith. In addition, there is also a significant tendency of research to be focusing more on the contextual the use of language. Research on the genre of legendary tales about the life of the Iban community has not yet been studied. Therefore, this study will fill in that gap of the past researches to signify the influence of animism in the traditional customs and culture of the Iban people by focusing on HIkayat Keling Gerasi Nading. The selection of the text Hikayat Keling Gerasi Nading is due to its recount of the ancient Iban life, in terms of customs and culture which includes the societal rules, beliefs and their way of living. Furthermore, the narration of the tale also contains the history and myths within the society. Therefore, this writing will identify and discuss the aspects of the influence of animism on the customs and cultures the Iban people in Hikayat Keling Gerasi Nading. 
INTERNATIONAL JOURNAL OF ACADEMIC RESEARCH IN BUSINESS AND SOCIAL SCIENCES

Vol. 8, No. 8, August 2018, E-ISSN: 2222-6990 @ 2018 HRMARS

\section{Methodology}

In this study, the researchers used the text Hikayat Keling Gerasi Nading by Jimmy Donald (1998) as the main text. This study adopted the qualitative research method which is the method of collection and the approach of Sociology of Literature by Alan Swingewood (1972). The principles of this approach are divided into three main principles, namely literature and society, social reflection and the position of author. The selection of this theory is due to its description of the reflection of events that happened to a society.

In addition, this theory also shows the close relationship between the literary work and the community and it also highlights the real life of the community in the literature. Literary writers are also free to choose the things that are considered to propel the audiences to obtain and enjoy the produced works of literature. This is because literary works became the new tools of dissemination to the community.

\section{Data analysis}

\section{The Influence of Animism}

The meaning animism according to Eshah a. Wahab (2012) is the worship and faith in superstitions, invisible beings, powerful dark forces, and magic. While according to Kamus Dewan (2010) the influence of animism is the belief that each body of stone, wood and other similar objects in having a spirit. Moreover, animism also refers to as having faith in a type of spirit or soul. Furthermore, animism can also be said that every creature, object, or plants have a spirit or (soul). This spirit is immortal nor can it disintegrate like a human body. Other than that, animism believes in the existence of supernatural creatures which are creatures that exist but cannot be seen with the naked eye. These creatures are known as elves, ghouls, goblins, ghosts and the like. This study includes believing in faith healers and witch doctors, in spirits or souls of the dead, in the art of premonition and the relationship between man and animal.

\section{Believing in Faith Healers and Witch Doctors}

Consorting with faith healers and witch doctors is a practice and belief which is clearly described in the text of the Hikayat Keling Gerasi Nading. The Iban people trust witch doctors or better known as (manang) to be able to cure diseases. According to Jamilah Hj. Ahmad and Jonathan Sink (1989), manang is a faith healer or witch doctor in charge of treating the sick. Manang is the person who has skills and knowledge in the field of black magic and is able to unravel mysteries and provide answers to the strange illnesses suffered by humans as well as to create a variety of other knowledges. Not anyone can easily be considered as a witch doctor to take on the title and responsibilities, where they are to have extraordinary powers and magical elements. In Hikayat Keling Gerasi Nading, the belief in faith healers or witch doctors can be seen in the following excerpt:

"Sekiranya tangkal itu menjadi seorang manusia," kata Keling, "ia akan memegang peranan sebagai ayah kita."

Adik-beradiknya bersetuju lalu memberitahu ibu mereka supaya sampai dijampikan azimat atau tangkal itu untuk menjadi manusia dan memimpin mereka sebagai ayah.

"Apa salahnya kalau ada orang yang tahu," jawab ibu Keling, "tetapi siapakah yang sanggup untuk menjadikannya manusia?"

"Kami juga tak tahu," kata mereka, "tetapi kalau kamu yang tua tahu, boleh juga beritahu, supaya kita dapat mencuba." 
INTERNATIONAL JOURNAL OF ACADEMIC RESEARCH IN BUSINESS AND SOCIAL SCIENCES Vol. 8, No. 8, August 2018, E-ISSN: 2222-6990 @ 2018 HRMARS

"Bagaimana kalau kita menyuruh Nenek Kebayan atau Nenek Manang yang bernama Sindon Dayang Semanang yang tinggal di Gelong Batu Nakong Nyingit Nyandar Nerabang," cadang ibu Pungga.

(Jimmy Donald, 1998:3)

["If the talisman becomes a human," said Keling, "it will take on the role as our father." His sisters agreed and went on to tell their mother so the enchantment would be cast upon the amulet or talisman to become human and lead them as a father. "What could it hurt if people would know," replied Keling's mother, "but who is willing to make it human?" "We don't know," they said, "but if you elders know the way, you can tell us so that we can try." "How about we asked Nenek Kebayan or Nenek Manang named Sindon Dayang Semanang who lives in Gelong Batu Nakong Nyingit Nyandar Nerabang," suggested Pungga's mother.]

(Jimmy Donald, 1998:3)

Based on the excerpt above, the Iban people are described as highly trusting on the ability of witch doctors or faith healers. Furthermore, the Iban people in the excerpt above believe that a witch doctor or faith healer is able to revive the spirit of a deceased person. It is evident that the existence of witch doctors are so much needed that their position are regarded as the highly respected in society, next to tuai rumah (head of the longhouse). This is mainly due to the Iban belief in dead spirits and it is vital to them to be able to communicate with the invisible, better known as antu (ghost). In addition, if they were to make requests with an antu (ghost) then the request will be made true with the power of the witch doctors that are otherworldly and more extraordinary than regular people. Thus in the perspective of the Iban community, they strongly believe in the ability of a witch doctor or faith healer, who are believed to have sacred powers and magic, similar to deities and God himself. Meanwhile, the word (Nenek Manang) refers to grandmother or an elderly.

Maka pergilah mereka berjumpa Nenek Manang. Apabila Sindon Dayang Semanang tiba di Panggau Libau, Keling dan adiknya pun masuk ke bilik mereka dan mengeluarkan tangkal. Tangkal itu kemudian diikat di tiang ruai. Nenek Manang pun memulakan mantera dan jampinya.

(Jimmy Donald, 1998:4)

[Then off they went to Nenek Manang. When Sindon Dayang Semanang arrived at Panggau Libau, Keling and his brother went into their room and brought out the talisman. It was then tied onto a pole in the gallery. Nenek Manang started her mantra and spell.]

(Jimmy Donald, 1998:4)

The meaning of mantra according to Ismail Hamid (1988) is the words or speech that specifically produces magical powers. The use of mantras or spells is composed using specific language arrangement in which the meaning cannot be understood by regular people who do not learn occultism or black magic. Furthermore, the words chosen are also believed to have supernatural strength and unusualness to influence the desired intentions. Therefore, the witch doctor, faith healers or manang are the chosen ones where only they are capable of curing illnesses and granting prayers of the people. This is clearly illustrated in the excerpt where Nenek Manang prays to the gods to make the talisman morph into the figure of a man that was desired by the character Keling, as seen in the excerpt above. By the virtue of immense power and magic, the figure of a human was borne from the talisman fastened at the pole. 
In continuance, the life story of the Iban people in the chosen tale is related with Sociology of Literature by Alan Swingewood (1972). That is to say that the work is a social reflection, where in this sense, it means the story shown is a true reflection of life which had happened in the community through the experience and observation by the authors. Moreover, the way of life is still practiced by a few Iban people who still profess belief in animism which comprises of the elderly and the ones who reside in rural areas. While the middle-aged and young living in developed areas became Christians where consorting with witch doctors and faith healers lack acceptance and they are not welcomed in their circles.

\title{
Belief in Spirits or Souls of the Dead
}

Jamilah $\mathrm{Hj}$. Ahmad and Jonathan Sink (1989) said that the Iban community believe in the existence of life after death. This is because in the Iban belief, when people die, their soul is referred as spirit or (semengat) that can be risen again. This belief is reflected in the character Keling who believes that by using a talisman, his father can be revived from death. This is clearly shown in the following excerpt:

\begin{abstract}
"Sekiranya tangkal itu menjadi seorang manusia", kata Keling, "ia akan memegang peranan sebagai ayah kita."

Adik-beradiknya bersetuju lalu memberitahu ibu mereka supaya sampai dijampikan azimat atau tangkal itu untuk menjadi manusia dan memimpin mereka sebagai ayah...Selepas tujuh tahun, tujuh bulan dan tujuh hari Nenek Manang menjampikan tangkal itu maka bertukarlah ia menjadi seorang manusia. Dia diberi nama Bujang Tuai Besepai Pemanjai Lintang, Guna Tuai Putus Penanchang, Tujuh Taun Tuai Ari Indai, Tujuh Taun Tuai Ari Apai, Nadai Bok Semina Gundai Baka Iko Buntal Belenang. Padan dengan nama yang diberikan, dia memang mempunyai rambut yang sedikit sahaja, seperti ekor ikan untal yang berenang.
\end{abstract}

(Jimmy Donald, 1998:4)

["If the talisman becomes a human", according to Keling, "it will take on the role as our father." His sisters agreed and went on to tell their mother so the enchantment would be cast upon the talisman or amulet to become human and lead them as a father...After seven years, seven months and seven days, Nenek Manang cast a spell on the talisman and so, it became man. He was named Bujang Tuai Besepai Pemanjai Lintang, Guna Tuai Putus Penanchang, Tujuh Taun Tuai Ari Indai, Tujuh Taun Tuai Ari Apai, Nadai Bok Semina Gundai Baka Iko Buntal Belenang. How fitting was the name, for he has very little hair, much like the tail of a swimming untal fish.]

(Jimmy Donald, 1998:4)

Based on the above excerpt, it is shown that the Iban community believe that the spirits of the dead can be resurrected and live amongst them and be alive again. Through this belief, it is related with celebrations and rituals of Gawai Antu. Gawai Antu is a ritual which involves offerings of glutinous rice, tuak and the act of slaughtering a pig as worship to the dead. This gawai is the most expensive ceremony for the Iban community. Furthermore, the Iban people also believe that the spirit of the dead can provide assurance of health, wealth and many harvests of their paddy fields. Other 
INTERNATIONAL JOURNAL OF ACADEMIC RESEARCH IN BUSINESS AND SOCIAL SCIENCES

Vol. 8, No. 8, August 2018, E-ISSN: 2222-6990 @ 2018 HRMARS

than that, the Iban people also believe that upon visiting cemeteries, they are required to bring food where in their view, the ghost (antu) or the dead will feed on the food. This is parallel with the sociology of literature which highlights that literary works do have important information about a society in terms of environment, era and culture which can be found in the literary work itself. This means that the contents of the literary works do describe and submit information about the social, culture, economy and politics of a society directly in the work.

\section{Belief in Art of Premonition}

The art of premonition is known as the ability of reading into someone's future and those who learn the art can also read minds. According to Hashim Awang (1984) and Salmah Jan Noor Muhammad (2015), the art is also associated with dreams, where through their life experience, the community often consider it to be meaningful. In addition, the art also reflect the intellect of the community in amassing a wide range of knowledge.

Yusmilayati Yunosi and Muammar Qaddafi Hanafiah (2017) said that the art of premonition has long ago became an important practice in society. This knowledge soon became a guide in daily life, given its importance as a means to forecast anything that may happen in the future and also for certain purposes especially in predicting weather, birthdates and wedding dates. This prediction is based on changes in nature, certain animal symbols, dreams and actions of a person.

Other than that, the art of premonition is one of the essential elements of life particularly in the Iban community. The Iban people believe in a variety of predictions such as the ones associated with good and bad luck which can be predicted through dreams and animal sounds. According to Vinson (1978) who states that this premonition can be obtained by listening to the sounds of animals in the forest such as ketupong, kikih or embuas, bergai, papu or senabong, pangkas or kutok and nendak. Even until now, the lban community still believe in the art of premonition to have an effect on all aspects of daily lives, for example in activities such as hunting, rooster fights, paddy farming, marriage and others. In Hikayat Keling Gerasi Nading, the belief in premonition is displayed in the excerpt below:

“Malam tadi saya juga bermimpi,"sahut Renggan. "Apabila meninggalkan pelantar kita yang digunakan kita untuk tidur di rumah panjang, dan mula berbaring di atas tikar yang diperbuat daripada daun-daun, menggunakan akar-akar untuk bantal dan embun malam sebagai selimut, saya bermimpi berjalan di kuala sebuah sungai dan menangkap ikan yang sedang bertelur di sana." "Dahulu, apakah erti mimpi seperti itu kepada kamu?" Tanya Bongkok. "Dahulu ia membawa maksud bahawa kita akan berjaya dan kita akan berasa letih memenggal kepala musuh kita daripada tubuh mereka," sahut Renggan.

(Jimmy Donald, 1998: 201)

["Last night I dreamt," said Renggan. "When we left the platform we slept in at the longhouse, and started to lie down on mats made of leaves, using roots for a pillow and blanketed by the morning dew, I dreamt of running at the confluence of a the river and catching fishes that has laid eggs there." "First, what is the meaning of a dream like that to you?" asked Bongkok. "First it means that we will succeed and we will feel tired after beheading our enemies," answered Renggan.] 
INTERNATIONAL JOURNAL OF ACADEMIC RESEARCH IN BUSINESS AND SOCIAL SCIENCES Vol. 8, No. 8, August 2018, E-ISSN: 2222-6990 C 2018 HRMARS

(Jimmy Donald, 1998:201)

Based on the excerpt above, it portrays the character of Renggan whose dreams can be used to predict his fortune, be it good or bad. Renggan dreamt about ngayau (beheading). The dream showed them their success in defeating their enemies where many heads will be brought back to their longhouse. Thus it is clear that the Iban practice of premonition can provide beneficial outcomes to them by determining whether their future undertakings would run smoothly or not. Dreams also influence their daily activities such as hunting, farming, and rooster fighting. This practice is still undergoing now in modern times, primarily within Iban communities living in rural areas.

"Kamu kamu mendengar bunyi burung yang membawa nasib baik sahaja. Dalam perjalanan, kamu harus juga mencari tanda-tanda yang lain. Jika kamu melihat rusa sedang makan, bangkai burung terbaring di atas telurnya ataupun seekor cicak menelan ekornya maka kamu akan membawa pulang kejayaan."

(Jimmy Donald, 1998: 6)

["You only hear upon birds who bring good luck. During the journey, you should also look out for other signs. If you see a deer eating, a bird carcass lying on its eggs or a lizard swallowing its tail, then you shall return with success. "]

(Jimmy Donald, 1998:6)

In the Iban faith, they believe in elements of nature like animals, animal sounds, rivers and the like, which could bring good or bad omens to them. The art of premonition is important to them when undergoing activities such as foraging the forest for food, rooster fights, paddy farming and not to forget, the activity of ngayau. To this day, the belief in the art of premonition is still practiced by a few Iban people who professed belief in the ancient Iban beliefs (pengarap lama). This belief is identified in the rural areas of Sarawak where it is practiced by elders of the Iban community. In line with the approach of the Sociology of Literature by Alan Swingewood (1972), both excerpts are the tales that can be recorded into historical documents. This document refers to the reactions of the timeline, setting and the society within the produced literary work. This is because the experience of the authors is the influence behind the writing and it is inseparable from the author's writing because the author himself is an Iban native. Therefore the events in the story can be called as a mirrored reflection of the real Iban life in which the author has experienced.

\section{Relationship between Man and Animal}

The Iban community is known as a brave, hardworking and empowered community. There are several occurrences in the text which tells about humans and animals who can shapeshift, for example animals that can change into man and man who can marry animals. This is clearly reflected in the excerpt of the Hikayat Keling Gerasi Nading:

Isteri Keling bertukar menjadi kijang. Keling duduk menyandar di pohon kayu melihat apa yang terjadi. Tempat tinggalnya menjadi hutan rimba dan anaknya juga bertujar kijang. Anak kijang itu mengelilingnya tetapi apabila Keling hendak menangkapnya ia pun lari mendapat ibunya.

(Jimmy Donald, 1998: 27) 
INTERNATIONAL JOURNAL OF ACADEMIC RESEARCH IN BUSINESS AND SOCIAL SCIENCES Vol. 8, No. 8, August 2018, E-ISSN: 2222-6990 @ 2018 HRMARS

[Keling's wife turned into a small deer. Keling was sitting against a tree branch, seeing it happened. Their home became the jungle and his son also turned into a small deer. The deer offspring ran around him but when he tried to catch it, it ran away towards his mother.]

(Jimmy Donald, 1998:27)

The above excerpt describes the close relationship between animals and the Iban community. Amongst the contributing factors would be their jungle residence and lifestyle. It also shows the Iban people as having incredible power, as those having magical forces such as witch doctors and faith healers. This is because the Iban community are comprised of mundane people and people who are able to communicate and marry animals.

Keling bertemu dengan Endu Puteri Berenai Tabor Sugi Endu Ensong Lua Genali anak Raja Ular Sawa Becoreng Gelung. Ayahnya belum ada yang dapat melihat tetapi mengikut cerita yang Keling dengar ayahnya sebesar kepuk padi yang dibuat daripada kulit kayu. Matanya sebesar mangkuk. Puteri Berenai sememangnya kekasih Keling.

(Jimmy Donald, 1998: 33)

[Keling met Endu Puteri Berenai Tabor Sugi Endu Ensong Lua Genali anak Raja Ular Sawa Becoreng Gelung. None has seen the father but according to stories, her father is as big as a paddy granary made from the tree bark. His eyes are as large as bowls. Puteri Berenai is truly the beloved of Keling.]

(Jimmy Donald, 1998:33)

Furthermore, the Iban community is also immersed in mysticism such as in the knowledge of the supernatural where they are able to have connections with animals. Not to mention, according to the Iban people, animals are also the incarnation of their cursed kin who married snakes, deer and the like. Thus, there are a handful of Iban who are abstinent in consuming deer and snakes because it is considered as a taboo since their ancestors was married to those animals such as in Hikayat Keling Gerasi Nading. In the event of a violation, it can bring upon insanity and death. That is the reason the Iban people are known to be traditionally minded where they keep to to their culture in their lives to avoid curses and destructions in their lives. Such as the Iban saying goes "Berjalai betungkat ke adat, tinduk bepanggalka pengingat" which means "to walk pillared by customs, to sleep cradled with memories" which serves a guide in their lives. The purpose of this saying, (wherever we may go, our customs is our guide and let us always be mindful as to not easily forget our roots).

From the findings of the excerpt above, the story of Hikayat Keling Gerasi Nading has a positive outlook. It means an event or occurrence that has happened in reality or has ever happened is used as a source of information and reference in the narration. According to Alan Swingewood (1972) the role of literature is as a source of documentation and in it there are an abundance of life lessons to be learned.

\section{Summary}

The summary of the study on the influence of animism is found through observation is the mirrored reflection of the Iban community. Among them is the belief in witch doctors and faith healers, belief in the spirits or souls of the dead. They also have belief in spirits and the souls of the dead, where the Iban people now still perform the rituals and ceremonies of Gawai Antu which is the gawai of prayers and celebrations of people who have died. Other than that is the belief in the art of premonition to interpret dreams, sounds of birds and animals which is still trusted by the lban people in living in rural 
areas especially the elderly. Last but not least is the relationship between man and animal. Through thorough investigations, it is found that human and animals have a special relationship that is marriage. It is often found in dreams because the Iban people believe that dreams bring news which may be true or otherwise where this is in accordance of their belief in premonition. Furthermore, the effect of the interspecies marriage caused some Iban families to be prohibited to kill and hunt animals such as snakes, deer and so on due to it being a taboo. The selection of the study is in line with the opinion of Harishon Radzi and Phylisia anak David (2012) where texts such as the story of the legendary tale is a recount of the daily lives of a society, parallel to the idea of Literary Sociology by Alan Swingewood (1972) in which the story of the literary work is the reflection of a society.

\section{Conclusion}

In conclusion, based on analysis of the influence of animism on the traditional customs and culture of the Iban people in Hikayat Keling Gerasi Nading, gives a huge impact on the development of knowledge for the community, not only restricted to the Iban society. Therefore this study is considered essential to the interests of students of Literature because literary works is an important medium to instil a sense of well-being in students. Literary works also have intellect, sensitivity, expressed and implied meanings which should be examined as it can provide many benefits to people arts and society. In addition, this research is considered vital for authors. In this study, the author is able to summarize Iban life to be wealthy of traditional customs and culture in the literary works. In addition, the author can also deeply explore the way of Iban living in detail based on this study. This study is also considered essential to cultural officers. Malaysia is known to be a country of having various ethnic groups who each have a variety of different cultures and customs of their own. Thus, this study may help cultural officers to some extent to learn about the Iban culture which is the reflection of the real life of Iban people in Sarawak. Moreover, this research is also important to publishers where they can also make this study as a reference about the titles that have been written by the authors of literary works. This study could also produce a better quality of writing in this area and is also able to attract the interest of the public to venture into this field to multiply the various forms of this study and so on. The study is also able to provide many benefits to publishing houses as an economic platform which is commercially important to the publisher. Lastly is for future researchers. This study can be used as a reference to know the identity of the Iban community by further learning their customs, culture and faith. Researchers also can learn and observe the highlighted aspects of this study in higher clarity where it concerns their faith and beliefs. In this regard, it is hoped that the forthcoming studies will give focus on the leadership roles in the Iban community, be that they use text or a field research as the main study guide.

\section{Corresponding Author}

Jacqlyn Patricia Anak Jelani

Universiti Putra Malaysia

43400 Serdang

Selangor Darul Ehsan

Malaysia

Email: jacqlynpatricia@gmail.com 
INTERNATIONAL JOURNAL OF ACADEMIC RESEARCH IN BUSINESS AND SOCIAL SCIENCES

Vol. 8, No. 8, August 2018, E-ISSN: 2222-6990 @ 2018 HRMARS

\section{References}

Bakar, A. H. (1997). Sebelas Rejab (Pengenalan). Kuala Lumpur: Dewan Bahasa dan Pustaka.

Anna, D., Zarina, M. S., Bernice H. \& Mohd, G. A. (2011). Pengaruh Ngayau atau Headhunting dalam Penciptaan Motif-Motif Tekstil Pua Kumbu Masyarakat Iban di Sarawak. Jurnal Melayu, 7, $303-316$.

Anwar, R. (1986). Kesusateraaan dan Masyarakat Satu Pendekatan Mendekati Kesusasteraan. Baharuddin Zainal. Pngr. Kuala Lumpur: Dewan Bahasa Dan Pustaka.

Asmiaty, A. (2011). Ngayau Sebagai Sebuah Novel Berwarna Tempatan: Satu Kajian Sosiologi Sastera. Jurnal Pusat Penataran IImu \& Bahasa, 17, 39-56.

Asmiaty, A. \& Lokman, A. S. (2016). Novel Bagaton Dan Ngayau: Satu Analisis Menerusi Kaca Mata Gagasan Persuratan Baru. Jurnal Pusat Penataran IImu \& Bahasa, 23, 43-60.

Benedict, S. (1976). Iban Way of Life. Kuching: Borneo Literature Bureau.

Benedict, S. (1980). Iban Adat and Augury. Penang: Penerbit Universiti Sains Malaysia.

Chemaline, O. (2006). Leka main Puisi rakyat Iban: Satu analisis bentuk dan fungsi. Tesis Doktor Falsafah. Universiti Sains Malaysia: Pulau Pinang.

Chong, S., Herpanus, A. \& Remmy, G. (2014). Hubungan Linguistik Bahasa Iban Dan Bahasa Desa. Jurnal Pusat Penataran IImu \& Bahasa, 21, 99-111.

Taylor, E. B. (1965). Theories of Primitive Religion. Oxford: The Claredon Press.

Eshah, A. W. (2012). Unsur-Unsur Agama, Ritual dan Sinkretisme Masyarakat Bajau Omadal. International Seminar on Community Development, 7-9 April 2012, Universiti Malaysia Terengganu.

Hamdan, A. W., Imran, H. A, Mohammed, A. \& Khazriyati, S. (2016). Analisis Eufemisme Kematian Masyarakat Melayu Sarawak dari Perspektif Semantik Kognitif. GEMA Online Journal of Language Studies. 16(2), 53-71.

Harishon, R. \& Phylisia, A. D. (2012). Unsur Eufemisme dan Perumpamaan dalam Teks Hikayat Iban. Jurnal Linguistik, 16, 75-87.

Hashim, A. (1984). Kesusasteraan Melayu dalam Kritikan dan Sejarah. Petaling Jaya: Penerbit Fajar Bakti Sdn. Bhd.

Henry, G. N. (1998). Iban Rites of Passage and Some Related Ritual Acts a Description of Forms and Functions. Kuching: Dewan Bahasa dan Pustaka.

Ismail, H. (1988). Masyarakat \& Budaya Melayu. Kuala Lumpur: Dewan Bahasa dan Budaya.

Jamilah, Hj. A. \& Jonathan, S. (1989). Cerita Rakyat Iban. Kuala Lumpur: Dewan Bahasa dan Pustaka. Jimmy, D. (1998). Hikayat Keling Gerasi Nading. Kuala Lumpur: Dewan Bahasa dan Pustaka.

Kamus Dewan. (2010). Kuala Lumpur: Dewan Bahasa dan Pustaka.

Noria, T. \& Anna, D. (2015). Pengamalan Muzik Tradisional Taboh dalam Budaya Iban di Sarawak. Journal of Borneo-Kalimantan, 2(1), 71-78.

Salmah, J. N., Muhammad. (2015). Strategi Utusan Kerajaan dalam Menjalin Hubungan Diplomatik Pada Zaman Kesultanan Melayu. Pendeta Journal of Malay Language, Education and Literature, 5, 111-137.

Saptiana, S. (2017). Unsur-Unsur Budaya Dayak Iban dalam Novel Keling Kumang Karya Ray Masri Sareb Putra. Jurnal Pendidikan Bahasa, 6(1), 37-50.

Swingewood, A. \& Diana, L. (1972).The Sociology of Literature. Paladine. 
INTERNATIONAL JOURNAL OF ACADEMIC RESEARCH IN BUSINESS AND SOCIAL SCIENCES

Vol. 8, No. 8, August 2018, E-ISSN: 2222-6990 @ 2018 HRMARS

Vinson, H. Sutlive, Jr. (1978). The Iban of Sarawak: Chronicle of a Vanishing World. Waveland Press, Incorporated.

W. Howell and D.J.S Bailey. (1900). A Sea Dyak dictionary. Singapore : American Mission Press.

Yusmilayati, Y., Muammar, G. H., M, Norizam J. \& Zubir, I. (2017). Komunikasi Bukan Lisan: Alamat Kedutan (Denyutan) Berdasarkan Mujarrobat. Jurnal Melayu, 12, 391-406. 